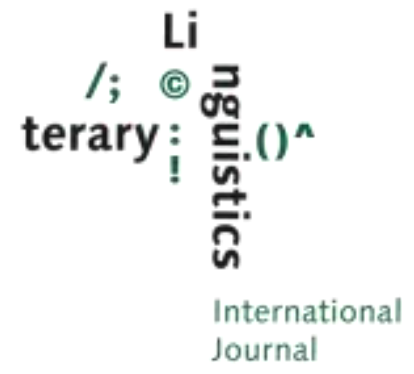

\title{
Literary Translation as Language Contact: A Pilot Study on the Finnish Passive
}

\author{
Leena Kolehmainen \& Helka Riionheimo, University of Eastern Finland
}

Keywords:

Literary translation, language contact, corpora, passive
Abstract: This article approaches literary translation from a contact-linguistic perspective and views translation as a language contact situation in which the translator "moves" between the source and target language. The study touches upon the possible linguistic effects of the source text on the translated text and relates the translation-mediated cross-linguistic influence to other language-contact situations. The study investigates the use of Finnish passive in a corpus of literary texts consisting of Finnish translations from Estonian and German and comparable non-translated Finnish literary texts. The translated texts are compared with non-translated ones by using corpus-linguistic tools, and the results are related to a previous contact-linguistic study on the use of the Finnish passive in spoken interviews of Finnish migrants in Estonia. The main objective is to test methodological tools that could be used for this kind of comparative purposes. In addition, the study approaches the question whether translation as a type of language contact affects the use of the Finnish passive in a similar way as an oral language contact situation. All in all, the study shows that there are some features that differentiate the investigated literary translations from non-translated Finnish texts but the evidence is not unambiguous. The article discusses the possible reasons for the mainly non-conclusive results of the analysis and points out factors that should be taken into account in future studies, such as the size of the sub-corpora and the possibly biased text or genre specific stylistic characteristics. The methodology clearly has to be adjusted and more in-depth methods developed in order to acquire a fuller picture of the Finnish passive in literary texts and to confirm what is author, translator, genre or source-language specific in the use of the Finnish passive.

\section{Introduction}

In this article ${ }^{1}$, literary translation is approached from a contact-linguistic viewpoint and regarded as a language-contact situation in which the translator "moves" between two (or more) languages when creating a new target-language text on the basis of a source text written in another language (see e.g. Kolehmainen et al. 2014; Kranich et al. 2011; Kranich 2014; Lanstyák \& Heltai 2012; Ožbot 2014; Riionheimo et al. 2014). The study touches upon the

\footnotetext{
${ }^{1}$ We would like to thank the anonymous reviewer and the editors of this volume for valuable feedback on an earlier version of the text. We also express our gratitude to Dr. Jukka Mäkisalo for checking our statistical calculations.
} 
possible linguistic effects of the source text on the properties of the translated target text and relates the translation-mediated cross-linguistic influence to other language-contact situations. The central goal of this article is to test methodological tools that could be used in this type of comparative research and to provide insights into how the tool set possibly could be developed and adjusted in order to investigate the question whether the linguistic outcomes of translational language contact are typical of and restricted to translation or whether they are shared by other language contacts. Similar questions have recently been pursued in the contact-linguistic study of translation. The present article seeks to contribute to this emerging field in translation studies.

The above-mentioned questions are investigated by analysing the use of the Finnish passive in a corpus of literary texts which consists of Finnish translations from Estonian and German and comparable non-translated Finnish literary texts (matched in size and with regard to genre). The translated texts are compared with non-translated ones, and the results are related to a previous contact-linguistic study on the use of the Finnish passive in spoken interviews of Finnish migrants in Estonia (Riionheimo et al. 2014; see also Riionheimo 2013). According to the results of this previous study, the contact with the Estonian language has affected the use of the Finnish passive among a particular group of Finnish migrants living in Estonia. In the current article we examine whether similar contact effects can be observed in literary translations and whether they can be detected by using corpus-linguistic tools. Literary translations are chosen as a parallel to the spoken contact data due to their potential for displaying the two central prototypes of the Finnish passive: one which is more typical of spoken interaction and which authors and translators make use of in order to create the illusion of spoken language and colloquial style; the other, more typical of written varieties of Finnish and its properties, resembling the passive in the Germanic languages. Another common feature between these particular interview data and the literary translations is that they are both narrative in their nature as the interviewees were asked to tell about their life stories. The present study forms a part of larger research focusing on passive constructions and is to be understood and read as a preliminary pilot study. Here, the first steps are taken in order to test the methodological possibilities for investigating the Finnish passive in literary texts by utilising corpus-linguistic tools and to compare literary data with data from spoken interaction.

The paper is organized as follows: Section 2 entails an overview of the current state of the contact-linguistic study of translation, its central research questions and findings. In Section 3 we describe the special characteristics of the Finnish and the Estonian passive. Section 4 presents information about the corpora used in this study and the methods of inquiry. In Section 5 we report the steps of the empirical pilot analysis and relate its results to a previous study on the effects of the Estonian language on the Finnish passive. Finally, Section 6 summarizes the findings of the pilot and draws conclusions for prospective studies on the comparison of translational contact-effects with the outcomes of other language contact situations. 


\section{The emerging contact-linguistic study of translation}

Factors that cause language change and variation are numerous, and among them, the role of language contact is especially important (see e.g. Thomason 2001). Contact between speakers of different languages may take place in both written and spoken interaction in several different contexts, and translation, whose study lies at the heart of this paper, is but one possible type of language contact. Where there is multilingualism, there is translation in its various forms as well as cross-linguistic and cross-cultural encounters between the translator, the source and target language and the speakers of these languages. Although a self-evident mode of language contact, translation is largely neglected in major works on language contact (see also Kranich, Becher \& Höder 2011: 11). In translation studies on the contrary, the situation is slightly different, and a new research area which combines viewpoints of translation studies and contact linguistics has started to emerge in recent years. Cross-linguistic influence, i.e. the influence of a source text on the linguistic properties of a translation, has of course been discussed in translation studies since the beginning of the discipline, and it has been regarded as a possible "law" of translation which takes place regardless of the language pair (Toury 1995). Its effects have been investigated in the study of the universal hypotheses of translation (see e.g. Eskola 2004, Mauranen 2004), but its interrelation with the contact-linguistic framework is a new development (see also Lanstyák \& Heltai 2012: 100). Within this emerging framework, researchers have examined what kind of a contact situation translation is, where and how it operates and whether it shares properties with other language contact situations or is a special mode of contact that differs from them (see e.g. Kolehmainen 2013; Kranich, Becher \& Höder 2011; McLaughlin 2011; Ožbot 2014; Riionheimo et al. 2014).

The most vivid part of the emerging contact-linguistic study of translation has been corpus-linguistic. By studying features, uses and frequencies of linguistic items in electronic corpora consisting of translations (and possibly their source texts), researchers have examined translational contact effects from both a synchronic and a diachronic perspective. Previous studies entail abundant evidence for diverse contact effects in translated texts, making them different from comparable non-translated texts in the same language. For example, the frequencies of linguistic items with no straightforward counterparts in the source language have been shown to be atypically low in translations. In turn, items which have direct equivalents in the source language may show higher frequencies in translated texts than in comparable non-translated texts in the same language (Tirkkonen-Condit 2004; Eskola 2002; 2004; Becher, House \& Kranich 2009; Kolehmainen 2011a; 2011b). The source texts shape the use of target text items, and for example the use of speech act pronouns and the collocation patterns of particular linguistic items have been shown to be affected by the source language in translation (Mauranen 2000; Becher, House \& Kranich 2009; Mauranen \& Tiittula 2005). Despite these innovations, the linguistic properties of translated texts have been shown to correspond better with the prescriptive norm than the language of other native writers (Jantunen 2004), and translations may for example entail fewer loanwords than comparable non-translated texts (for anglicisms see Bernardini \& Ferraresi 
2011). In particular circumstances, the translation-mediated language contact has left permanent traces in the target language and led to a contact-induced linguistic change by introducing for example new stylistic features and affecting the use of native linguistic items. Translation-induced diachronic changes in different languages are discussed in the studies by Amouzadeh and House (2010), Baumgarten, House and Probst (2004), Baumgarten and Özçetin (2008), Steiner (2008) and Wurm (2008).

Kranich, Becher and Höder (2011), Kranich (2014) and McLaughlin (2011) discuss the possible factors affecting the outcomes of a translation-mediated contact and show that they are largely the same ones which operate in other language-contact situations. In contact-linguistics, the intensity and length of contact, sociopolitical dominance relations and the prestige of the source language are some of the factors which have been shown to influence what kind of linguistic features are adopted - or rejected - and how thoroughly a change is carried out (see e.g. Thomason \& Kaufman 1988 and Thomason 2001). According to Kranich, Becher and Höder (2011), Kranich (2014) and McLaughlin (2011), similar factors also operate in translation and affect its outcomes, ${ }^{2}$ but more empirical studies are still needed for a more diverse set of language pairs, cultures and historical periods. In addition, translation may interact and be intertwined with other simultaneous language contacts and strengthen their impact. This aspect, which was brought up by Neumann (2011), is another angle which clearly needs more empirical research. New data and studies are required for testing whether the linguistic outcomes of translation-mediated contact are similar to or different from the ones caused by other contact situations. Previous studies have suggested that similarities indeed exist and that translation and other contact situations may lead to identical linguistic variation and change (see also Kranich, Becher \& Höder 2011; Lanstýak \& Heltai 2012). Kolehmainen, Meriläinen and Riionheimo (2014) for example analyse the manifestations of a particular type of contact effect, which they call interlingual reduction. In their study, this term refers to the contact-induced lower frequency or reduction of target-language linguistic items not shared by both of the languages involved in the language-contact situation. They compare the effects of different language contact situations and show that interlingual reduction occurs both in attriting languages in a migration context, in the process of translating into ones' L1, and in L2 speakers' and bilinguals' L1, and is hence to be regarded as a natural part of multilingual language processing (see also Kolehmainen 2013). More empirical studies are, nevertheless, required, and since the comparison of the outcomes between translational contact and other contact settings has just begun, one may expect that major differences between the two will be discovered as well.

In the previous contact-linguistic study of translation, the researchers have not distinguished literary translation as a special field of translation, and to our knowledge the studies have not separated different forms of translation from each other. More empirical studies are hence needed to answer the question whether cross-linguistic influence is manifested differently in the different forms

${ }^{2}$ In the study of literary translation, similar observations were made by Even-Zohar (1990). 
of translation. One possible difference between the contact effects in literary translations and the outcomes of other language contacts may be caused by the fact that literary translation is an activity often operated by multilingual professionals. This is an important feature which distinguishes literary translation from many other contact settings in which ordinary multilingual speakers are involved. Literary translators are experts in both of their working languages, and nowadays many of them have received translator training. Solving problems and challenges caused by cross-linguistic and cross-cultural differences is one of the basic tasks of their linguistic "detective work", and for this work they have special tools at their disposal. Literary translators "move" between the source and target text and constantly monitor the interlingual matches they make during the translation process. In addition, these matches can be negotiated in co-operation with other experts, for example with the publishing editor. Literary translation is hence a contact situation in which the party producing the target text is a multilingual expert, and it is also, to some extent, a social phenomenon involving more than a single individual. In the previous study to which the results of the present study are related the language contact concerns spoken interaction and ordinary multilingual speakers without special linguistic training. The main results of this previous study are described in Section 5.2.

\section{Central characteristics of the Finnish passive}

This paper discusses the possible effects of translation-induced language contact on the use of the Finnish passive in literary translations from Estonian. The following examples, which are taken from the literary corpus of the present study, illustrate the properties of the Finnish passive. They show that the Finnish passive differs in many ways from the passive category in Germanic or many other Indo-European languages. The Finnish and Estonian passive, in turn, share many properties but show also some divergent features.

First of all, the Finnish passive is a synthetic category which is formed morphologically by utilising special passive morphemes. The passive predicate does not, however, agree with the preverbal - or any other - constituent; it is an impersonal predicate which is not inflected in number. Furthermore, the Finnish passive is a subjectless impersonal construction. Example (1) shows that, although the patient argument may occupy the typical preverbal subject position, it is not promoted from object to subject but maintains its object status and case marking.

$$
\begin{aligned}
& \text { Minuthan heitettiin ulos. } \\
& \text { I.ACC.CLIT throw.PASS.PAST out } \\
& \text { I was indeed thrown out. (Orig-Fin-Det) }
\end{aligned}
$$

\footnotetext{
${ }^{3}$ The abbreviations in the grammatical glosses are explained in the Appendix, the abbreviations used for the data in Section 4.
} 
This non-promotional nature of the Finnish passive has occupied many researchers, and some of them have suggested that the Finnish passive should not be considered a passive at all and that it should be described differently (see e.g. Shore 1986; Tommola 1993; Blevins 2003). Indefinite (Shore 1986) and suppressive (Tommola 1993) are examples of some of the alternative terms which have been proposed to replace the term passive in previous research (for an overview of previous terminological discussion see Makkonen-Craig 2005: 14-16).

In Finnish it is possible to use intransitive verbs in the passive voice. This is a major difference in comparison to English, in which intransitive verbs are excluded (see e.g. Quirk et al. 1985: 162), but not for example in comparison to German, in which it is possible to form passive predicates from intransitive verbs (see e.g. Duden 2009: 469, 547-548). In Finnish, there are as a whole few verbs from which passive predicates cannot be formed. In principle, it is possible to use any verb in the passive voice if the valency of the verb entails a human participant. In most cases, this human participant is an agent, but sometimes a participant in another semantic role is also possible. This means that in Finnish, the passive can also be formed from non-agentive verbs such as psychological verbs (e.g. kärsiä 'to suffer' see Ex. 2) whose subject is not an agent but an experiencer (Shore 1986; Vilkuna 2000: 138-144; Helasvuo 2006; VISK §1313-1325; Posio \& Vilkuna 2013). This is a feature which sets the Finnish passive apart from German, for example, where the passive can only be formed from agentive verbs. It is one of the error sources for Finnish-speaking learners of German as a foreign language who try to apply the same passive formation rule in German (examples from Hyvärinen 1996):

\begin{tabular}{|c|c|c|c|}
\hline Finnish: & $\begin{array}{ll}\text { Ennen } & \text { kärsittiin } \\
\text { Earlier } & \text { suffer.PASS.PAST }\end{array}$ & $\begin{array}{l}\text { usein } \\
\text { often }\end{array}$ & $\begin{array}{l}\text { tuberkuloosista. } \\
\text { tuberculosis.ELA }\end{array}$ \\
\hline German: & $\begin{array}{l}\text { *Früher wurde } \\
\text { Earlier PASS.PAST.3SG }\end{array}$ & $\begin{array}{l}\text { öfter } \\
\text { often }\end{array}$ & $\begin{array}{ll}\text { an } & \text { der } \\
\text { from } & D E F\end{array}$ \\
\hline & $\begin{array}{ll}\text { Tuberkulose } & \text { gelitten. } \\
& \\
\text { tuberculosis } & \text { suffered }\end{array}$ & & \\
\hline
\end{tabular}

The Finnish passive, nevertheless, also shows features in common with the passive category in the Germanic languages. One common feature is the function of the passive. Both in Finnish and in Germanic languages, the central function of the passive is to background the agent - or some other human participant and to foreground the patient (see Ex. 1) or the temporal or spatial circumstances (see Ex. 2). Examples (1) and (2) above show that this

\footnotetext{
${ }^{4}$ The corresponding, grammatically acceptable version in active could be for example: Früher litt man oft an Tuberkulose.
} 
foregrounded element often occupies the preverbal position in the passive clause (see also Kittilä 2000: 298).

Shore (1986; 1988), who compares the Finnish passive with Germanic and Romance languages, concludes that the Finnish passive does not constitute a unified category but has multiple functions and properties. She divides the Finnish passive into the W[ritten]- and S[poken]-prototype. This division has proven to be useful in our previous investigation in which we have compared the Finnish passive with the Estonian, English and German passive (see Riionheimo et al. 2014; Kolehmainen 2014). The W-prototype is typical of written language, and its functions and word order resemble the agentless passive in the Germanic languages: If the passive clause has a patient, it is typically located preverbally in the beginning of the sentence. In the S-prototype, in turn, the passive predicate often occupies sentence-initial position. This prototype is more typical of (but not exclusive to) spoken language - or of the representation of spoken language in Finnish literature. The following examples illustrate the W- and S-prototype (in this order). The English translation in (3) highlights the similarities between the English passive and the W-prototype. In (4), the active voice in the translation brings out the differences between English and Finnish.

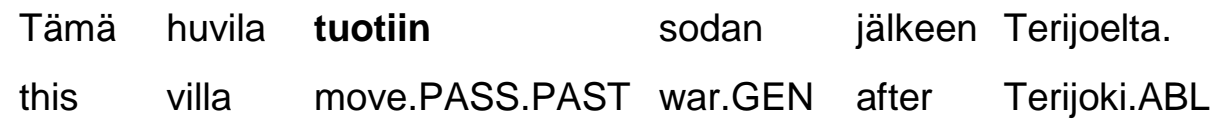

This villa was moved here from Terijoki after the war. (Orig-Fin-Det)

\begin{tabular}{|c|c|c|c|c|}
\hline $\begin{array}{l}\text { Lähdetäänpä } \\
\text { go.PASS.CLIT }\end{array}$ & $\begin{array}{l}\text { yhdessä } \\
\text { together }\end{array}$ & $\begin{array}{l}\text { lounaalle, niin } \\
\text { lunch.ALL so }\end{array}$ & $\begin{array}{l}\text { voit } \\
\text { can.2SG }\end{array}$ & $\begin{array}{l}\text { kertoa } \\
\text { tell }\end{array}$ \\
\hline matkastasi, & ministeri & ehdotti. & & \\
\hline trip.ELA.2PX & minister & suggest.PAST & & \\
\hline
\end{tabular}

Let's go together and have lunch so that you can tell about your trip, the minister suggested. (Orig-Fin-Det)

Although the agent participant is backgrounded, the Finnish passive nevertheless always presumes its presence. Most often, the passive refers to a plurality of the implicit agent (VISK §1323), and it enables an open reference to a person or to a group whose identity is not specified but must be inferred from the context (VISK §1315). The reference to the implied agent can be genericindefinite so that anyone in principle can be included (Posio \& Vilkuna 2013: 192). This is the case in Example (5), which describes how people in general see the city of Tampere (according to this speaker): 


$\begin{array}{llll}\text { Tamperetta pidetään } & \text { maan } & \text { tehokkaimpana } \\ \text { Tampere.PART } & \text { consider.PASS } & \text { country.GEN most-efficient.ESS } \\ \text { aluekeskuksena }[\ldots] . & & \\ \text { regionalcenter.ESS } & & \end{array}$

Tampere is considered the most efficient regional center in the country. (Orig-Fin-Det)

Often the passive is, however, chosen when temporally and spatially specific events are described in which the agent is a specific person or a specific person group (Posio \& Vilkuna 2013: 181; VISK §1325). In such cases the passive often overlaps with the first, second and third person (see e.g. VISK §106). In other words, the Finnish passive allows both speaker-inclusive and speakerexclusive interpretations. Especially in spoken language - i.e. in the S-prototype (see Ex. 4 above) - the passive is often speaker-inclusive so that the passive clause refers to an event in which the speaker is involved (Posio \& Vilkuna 2013). It is possible that the speaker-inclusive use of the passive has given rise to the rather particular use of the Finnish passive with the subject pronoun me 'we', see Example (6). This usage, which is quite widespread in Finnish dialects (Nirvi 1947: 34-40; Pertilä 2000), exclusively represents spoken language and colloquial style. ${ }^{5}$ In literary texts, it is exploited by authors and translators in order to create an illusion of spoken language (see e.g. Tiittula \& Schwitalla 2009; Tiittula \& Nuolijärvi 2013). In the speaker-exclusive passive clauses, in turn, the speaker does not belong to the group of possible agents. According to Shore $(1986 ; 1988)$, this is a typical feature for the W-prototype and written language (see Ex. 3 above).

$$
\begin{aligned}
& \text { Mitä muuta me voidaan tehdä paitsi peruuttaa kaikki? } \\
& \text { what else we can.PASS do except cancel everything } \\
& \text { What else can we do but cancel everything? (Orig-Fin-Det) }
\end{aligned}
$$

Although the Finnish passive has been examined extensively, its use in literary texts has not, to our knowledge, been investigated before. As compared to spoken data, one important difference has to be taken into consideration. In literary data, the speaker-inclusive and speaker-exclusive uses also cover the voice of the narrator: Whether s/he is entailed in the group of possible agent referents. What is known is that authors and translators utilise the speaker/narrator-inclusive passive (see Ex. 4 and 6) in order to imitate spoken language (see e.g. Tiittula \& Schwitalla 2009; Tiittula \& Nuolijärvi 2013), but for example the question of how the passive is used in narration and reported speech to

\footnotetext{
${ }^{5}$ The use of the passive form together with the pronoun me 'we' is today so widespread in colloquial Finnish that it has almost entirely replaced the original verb form inflected in the first person plural, and consequently the contemporary linguistic description considers these cases as part of the personal inflection in a paradigm of active inflection (see e.g. VISK §1272). In this study, however, we consider the use with pronoun as one extreme of the continuum of speakerinclusiveness and we have included these cases in our analysis. Analysing the passive forms in the Ingrian Finnish data (see Section 5.2) has shown that it is impossible to draw a strict line between the structure 'we' + passive and the subjectless speaker-inclusive use of the passive.
} 
represent different persons and voices - or to blur the person reference - has not yet been studied.

In Estonian the passive shows considerable syntacto-semantic similarities with the Finnish passive: In both languages the passive is a subjectless, nonpromotional and impersonal construction which backgrounds the agent participant. In addition, the semantic functions are similar: In Estonian too, the passive typically implies a plurality of human agents whose identity is left open but can be interpreted by relying on contextual and situational clues (see Ex. 7; for Finnish-Estonian comparisons see e.g. Tommola 1993: 72-80; Blevins 2003: 482-489; Kaiser \& Vihman 2006). Pragmatically these two closely related languages resemble each other as well: in both Finnish and Estonian, the passive is used in situations in which one wishes to avoid mentioning the human participant or addressing her/him directly (see Ex. 8; for Finnish see e.g. Posio \& Vilkuna 2013: 181; Shore 1988; for Estonian EKG I §54, Torn-Leesik \& Vihman 2010: 327-328). In both languages, the passive can be referentially generic so that the implied human participant can in principle be anyone (see Ex. 9). Alternatively the passive can be speaker-exclusive if a temporally or spatially specific event is referred to (see Ex. 10). There is, however, one major difference between the Finnish and Estonian passive: Speaker-inclusiveness is a function which is much more typical of Finnish, and the use of a passive predicate with the first person plural subject pronoun is not possible in Estonian at all (see Ex. 6 above) ${ }^{6}$. In Estonian, the passive is clearly more speakerexclusive (see e.g. Jokela 2012: 180, 208). This cross-linguistic difference is reflected in the results of the previous contact-linguistic study in which the impact of the Estonian passive on the Finnish passive was investigated and to which the results of the current paper are related (see Section 5.2).

$$
\begin{array}{ll}
\text { Seal magatakse. } & \\
\text { there sleep.PASS }
\end{array}
$$

People are sleeping there (Kaiser \& Vihman 2006: 114)

$\begin{array}{lcll}\text { Käesolevas } & \text { töös } & \text { vaadeldakse } & \text { eesti } \\ \text { this.INE } & \text { work.INE } & \text { examine.PASS } & \text { Estonian.GEN } \\ \text { keele } & \text { käänamissüsteemi } & \text { kujunemist. } \\ \text { language.GEN } & \text { declination.system.GEN } & \text { development.PART }\end{array}$

This work examines the development of the Estonian declination. (EKG I §54; glosses and translation by present authors)

\footnotetext{
${ }^{6}$ The passive is an old construction in Finnish and Estonian, derived from their common protolanguage (late Proto-Finnic). The use of the passive predicates with the first person plural subject pronoun is a later development and its origin has been located in the Savo dialect of Finnish and dates from the 17th century (Nirvi 1947). Therefore this phenomenon is not known in other Finnic languages.
} 
(9)

$\begin{array}{lll}\text { Supi juurde } & \text { süüakse leiba } \\ \text { soup.GEN to } & \text { eat.PASS } & \text { bread.PART }\end{array}$

One eats bread with soup. (EKG II §490; glosses by present authors, translation by Torn-Leesik 2015: 31)

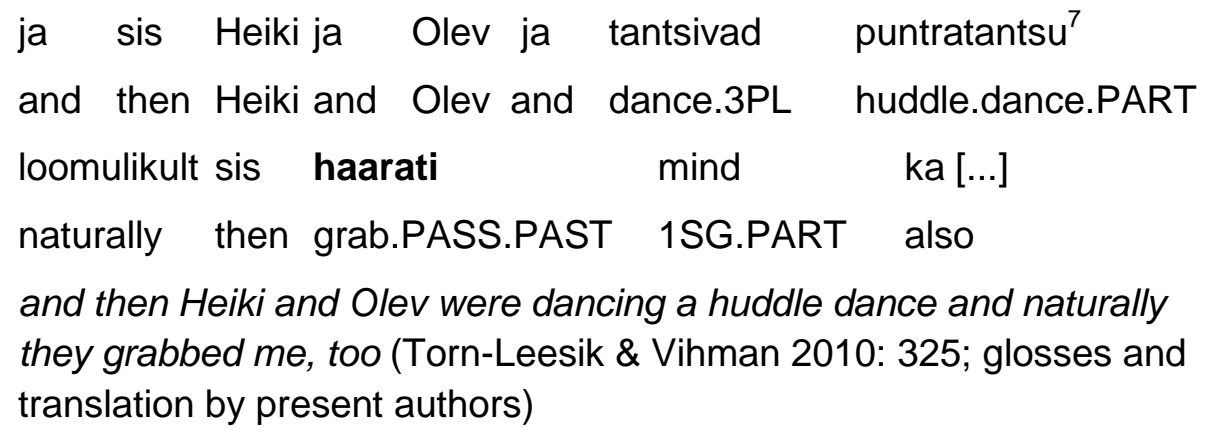

\section{Material}

The uses of the Finnish passive are investigated in and compared between a set of sub-corpora: Finnish literary texts translated from two different languages, Estonian and German, and non-translated Finnish literary texts. The breakthrough of this kind of monolingual comparative approach took place in the 1990's in the corpus-linguistic study of the universal hypotheses of translation (see e.g. Baker 1993), a paradigm within which cross-linguistic influence and source-language-dependent variation in translated texts was also investigated (see e.g. Mauranen 2004). Monolingual comparison reveals the first hints for cross-linguistic influence in translation: What is typical of translations from a particular source language as compared to translations from another source language and non-translated texts in the same language? The next step, which goes beyond the scope of the present pilot study, would be to compare the translated texts with their originals. According to Bernardini (2010), this final step is needed in order to ensure the cross-linguistic influence discovered in the monolingual comparison. ${ }^{8}$

For the comparison, four sub-corpora were formed that contain both translated and non-translated Finnish texts. The sub-corpora are presented in Table 1. The bibliographical data of the texts are available in the References. The first subcorpus Est-Fin contains Finnish literary texts translated from Estonian, the second corpus Ger-Fin Finnish literary texts translated from German. The two other sub-corpora entail Finnish non-translated texts (Orig-Fin-Det and Orig-FinLit). All texts in the four sub-corpora represent contemporary literature from the 1980 's and 1990's, occasionally from the 2000's.

\footnotetext{
${ }^{7}$ This excerpt represents spoken language; the transcription has been simplified by taking out the additional notation.

${ }^{8}$ Furthermore, data for translation processes (such as e.g. translators' think-aloud protocols and recordings of keyboard and screen activities) would be useful in the analysis of cross-linguistic influence in translation: According to Neumann (2011), published translations do not merely represent a translators' hand but also other possible participants' solutions (such as publishing editor's).
} 


\begin{tabular}{|l|l|l|}
\hline Sub-corpora & Abbreviation & Tokens \\
\hline 3 Finnish fictional texts translated from Estonian & Est-Fin & 194,773 \\
\hline 3 Finnish fictional texts translated from German & Ger-Fin & 186,860 \\
\hline 5 Finnish non-translated detective stories & Orig-Fin-Det & 197,349 \\
\hline 5 Finnish non-translated literary texts & Orig-Fin-Lit & 180,009 \\
\hline
\end{tabular}

Table 1: The sub-corpora of this study.

Most texts in the four sub-corpora are taken from the Corpus of Translated Finnish (see Mauranen 2004). In addition, two texts in the Ger-Fin sub-corpus come from the German-Finnish FinDe corpus. Two texts in the Est-Fin subcorpus were prepared especially for this study. The sub-corpora Est-Fin and Ger-Fin were matched in size and with regard to genre: Both sub-corpora entail three texts: one text is a detective/criminal story, two represent literary prose. Each text has been translated by a different translator. The translated subcorpora Est-Fin and Ger-Fin will be compared with each other and with two subcorpora that contain original Finnish non-translated prose. The sub-corpus OrigFin-Det contains the five Finnish original detective/criminal stories entailed in the section of original Finnish detective/criminal stories in the Corpus of Translated Finnish; the five literary texts in Orig-Fin-Lit, in turn, were randomly picked from the section of original Finnish literature in the Corpus of Translated Finnish.

Finally, a technical note on the compilation of the passive sample examined in the next section: The texts in the four sub-corpora are electronically available, but they have not been morphosyntactically annotated. In other words, it was not possible to detect the Finnish passive predicates automatically, and manual methods had to be developed. In the search for the passive predicates, the passive suffixes of present and past tense indicative forms and present tense subjunctive forms in affirmative clauses were utilised ${ }^{9}$ - these are morphologically and functionally almost unambiguously passive forms (see also Kolehmainen 2014, in which this method was successfully employed). The analysis in the next section hence concentrates on the occurrences of these passive predicates, and other passive forms are not included, such as passive participles, which are difficult to search manually due to the morphological properties of Finnish.

\section{The use of the Finnish passive predicates in the sub-corpora}

The central method of this study is monolingual variationist comparison which is carried out by making use of corpus-linguistic tools (WordSmith Tools, see http://www.lexically.net/wordsmith/). In addition, manual close-reading is needed. The following subsections report the results of some selected spot checks, which were carried out in order to test the possibilities - and possible

\footnotetext{
${ }^{9}$ The searched verb forms comprised the following passive suffixes: - taan/-tään, -daan/-dään, laan/-lään, -raan/-rään, -naan/-nään (present tense passive indicative in affirmative clauses), -tiin (past tense passive indicative in affirmative clauses) and -isiin (present tense passive subjunctive in affirmative clauses).
} 
limitations - of corpus-linguistic tools in the analysis of the Finnish passive in a literary corpus.

The goals of these spot checks are twofold: On the one hand, they serve to find out whether this kind of corpus-linguistic analysis allows detecting sourcelanguage-dependent features in the use of the Finnish passive or properties typical of Finnish translations as compared to non-translated Finnish literary texts. The manual sampling of the passive predicates without any morphosyntactic annotation constrained the technical possibilities in the analysis in many ways, but it was possible to investigate the following features and compare them between the four sub-corpora: the frequency of the passive predicates, the most frequent passive predicates and their properties, the predicates shared by the sub-corpora and their properties, and the collocations of the passive predicates. On the other hand, the analysis aims to find out whether the four sub-corpora differ with respect to the speaker-inclusive, speaker-exclusive and referentially open use of the Finnish passive. For this purpose, a manual semantic analysis of a restricted number of passive predicates was carried out in all sub-corpora.

\subsection{Passive predicates and their collocations}

The first step in our analysis is to detect the frequencies of passive predicates in our corpus. Table 2 shows the absolute and relative frequency of all passive predicates (collected using the method reported in Section 4 above) in the four sub-corpora. The relative frequency refers to the frequency of the passive predicates in proportion to the total number of running words in each subcorpus. Table 2 shows us that the relative frequency of passive predicates is highest in original Finnish literature (Orig-Fin-Lit) and lowest in translations from German (Ger-Fin). Translations from Estonian (Est-Fin) and Finnish-original detective/criminal stories (Orig-Fin-Det) are situated between these two. Although all the differences between the sub-corpora are statistically significant ${ }^{10}$, the frequencies do not distinguish translated texts from nontranslated ones. In addition, it is not clear whether they tell us anything about source-language-dependent properties and the translations from a particular language. The fact that such profiles cannot be detected can be interpreted in different ways: Either it is so that such profiles do not exist, that the use of the passive in Finnish is highly author- or translator-specific or that the sub-corpora in this pilot study are simply too small so that stylistic characteristics and preferences of individual texts blur the picture. What these data, however, indicate clearly is the need for a comprehensive corpus-linguistic quantitative study of the Finnish passive in literary texts in general and in individual literary texts that could be referred to for comparison. To our knowledge, such a study does not yet exist, and we do not yet know how the Finnish passive is used by

\footnotetext{
${ }^{10} \operatorname{In} \chi^{2}$ test, the $p$ values were the following: Est-Fin vs. Ger-Fin $p<.001$, Est-Fin vs. Orig-Fin-Det $p<.01$, Est-Fin vs. Orig-Fin-Lit $p<.001$, Ger-Fin vs. Orig-Fin-Lit $p<.001$, Ger-Fin vs. Orig-Fin-Det $p<.01$, Orig-Fin-Det vs. Orig-Fin-Lit $p<.001$.
} 
authors or translators, how frequently it is used in literary texts on average and how its different functions are utilised in literary texts (see also Section 3). ${ }^{11}$

\begin{tabular}{|l|r|r|r|r|}
\hline Sub-corpus & \multicolumn{1}{|c|}{$\begin{array}{c}\text { Passive } \\
\text { predicates in } \\
\text { total (tokens) }\end{array}$} & \multicolumn{1}{|c|}{$\begin{array}{l}\text { F/1000 } \\
\text { words }\end{array}$} & \multicolumn{1}{|c|}{$\begin{array}{c}\text { Different } \\
\text { passive } \\
\text { predicate } \\
\text { types }\end{array}$} & \multicolumn{1}{|c|}{$\begin{array}{c}\text { Type/token } \\
\text { ratio (\%) }\end{array}$} \\
\hline Est-Fin & 889 & 4.6 & 290 & 32.6 \\
\hline Ger-Fin & 616 & 3.3 & 239 & 30.9 \\
\hline Orig-Fin-Det & 774 & 3.9 & 286 & 37.0 \\
\hline Orig-Fin-Lit & 1,025 & 5.7 & 374 & 36.5 \\
\hline
\end{tabular}

Table 2: The absolute and relative frequency of the passive predicates in the four sub-corpora and different passive predicates' (types') share of all passive predicates (tokens).

However, the column for the type/token ratio in Table 2 gives a clearer profile for translated and non-translated texts and exposes one possible difference between translations and original Finnish literature. Type/token ratio refers to the share of different passive predicate types of all passive predicates. In both groups of translated texts, the number of different passive predicates is lower (30.9\% and $32.6 \%$ ) than in original Finnish detective/criminal stories (37.0\%) and literary prose (36.5\%). This quantitative result does not clearly set apart the two translated sub-corpora from each other, but it shows that the lexical variation of passive predicates is narrower in translations than in original Finnish detective/criminal stories and literary prose. This result is compatible with previous corpus-linguistic studies, according to which lexical variation in general tends to be narrower in translations than in comparable non-translated texts in the same language (see e.g. Laviosa 1996): Whereas translators rely on a model text and create a new text on the basis of an existing model, authors have freer hands and are not restricted in their solutions by another text (see e.g. Nevalainen 2003).

Table 3 below, in turn, lists the 15 most frequent passive predicates in the subcorpora. This list shows that there are in total seven passive predicates that in all four sub-corpora belong to the group of 15 most popular passive predicates: olla 'be', tehdä 'do', lähteä 'leave', mennä 'go', ottaa 'take', voida 'can, be allowed to, feel' and sanoa 'say'. The frequency of these passive predicates and their position among the 15 most common passive predicates varies in the subcorpora, but this variation does not allow us to conclude whether it is a characteristic emerging from the source language or caused by thematic or stylistic matters in the texts.

\footnotetext{
${ }^{11}$ In the present study, the texts in the four sub-corpora were analysed in groups and not individually. In order to find out whether there are differences in the passive use between the different books an additional step is required in which the analysis is repeated separately with regard to each text (16 in total). It is obvious that it is feasible to carry out this kind of analysis only after the corpus texts have been annotated.
} 


\begin{tabular}{|c|c|c|c|c|c|c|c|c|}
\hline & \multicolumn{2}{|r|}{ Est-Fin } & \multicolumn{2}{|c|}{ Ger-Fin } & \multicolumn{2}{|c|}{ Orig-Fin-Det } & \multicolumn{2}{|c|}{ Orig-Fin-Lit } \\
\hline & Freq. & Verb & Freq. & Verb & Freq. & Verb & Freq. & Verb \\
\hline 1. & 54 & $\begin{array}{l}\text { sanoa } \\
\text { say }\end{array}$ & 29 & $\begin{array}{l}\text { olla } \\
\text { be }\end{array}$ & 47 & $\begin{array}{l}\text { mennä } \\
\text { go }\end{array}$ & 53 & $\begin{array}{l}\text { mennä } \\
\text { go }\end{array}$ \\
\hline 2. & 27 & $\begin{array}{l}\text { olla } \\
\text { be }\end{array}$ & 25 & $\begin{array}{l}\text { sanoa } \\
\text { say }\end{array}$ & 33 & $\begin{array}{l}\text { lähteä } \\
\text { leave }\end{array}$ & 51 & $\begin{array}{l}\text { olla } \\
\text { be }\end{array}$ \\
\hline 3. & 24 & $\begin{array}{l}\text { panna } \\
\text { put }\end{array}$ & 19 & $\begin{array}{l}\text { panna } \\
\text { put }\end{array}$ & 32 & $\begin{array}{l}\text { olla } \\
\text { be }\end{array}$ & 33 & $\begin{array}{l}\text { tehdä } \\
\text { do }\end{array}$ \\
\hline 4. & 24 & $\begin{array}{l}\text { tehdä } \\
\text { do }\end{array}$ & 17 & $\begin{array}{l}\text { tehdä } \\
\text { do }\end{array}$ & 18 & $\begin{array}{l}\text { puhua } \\
\text { talk }\end{array}$ & 22 & $\begin{array}{l}\text { sanoa } \\
\text { say }\end{array}$ \\
\hline 5. & 24 & $\begin{array}{l}\text { lähteä } \\
\text { leave }\end{array}$ & 16 & $\begin{array}{l}\text { pitää } \\
\text { keep, like, } \\
\text { have }\end{array}$ & 18 & $\begin{array}{l}\text { sanoa } \\
\text { say }\end{array}$ & 22 & $\begin{array}{l}\text { voida } \\
\text { can, be } \\
\text { allowed } \\
\text { to, feel }\end{array}$ \\
\hline 6. & 24 & $\begin{array}{l}\text { mennä } \\
\text { go }\end{array}$ & 16 & $\begin{array}{l}\text { tarvita } \\
\text { need }\end{array}$ & 18 & $\begin{array}{l}\text { tehdä } \\
\text { do }\end{array}$ & 21 & $\begin{array}{l}\text { ottaa } \\
\text { take }\end{array}$ \\
\hline 7. & 23 & $\begin{array}{l}\text { kutsua } \\
\text { invite, call }\end{array}$ & 16 & $\begin{array}{l}\text { mennä } \\
\text { go }\end{array}$ & 17 & $\begin{array}{l}\text { tarvita } \\
\text { need }\end{array}$ & 21 & $\begin{array}{l}\text { tarvita } \\
\text { need }\end{array}$ \\
\hline 8. & 21 & $\begin{array}{l}\text { ottaa } \\
\text { take }\end{array}$ & 14 & $\begin{array}{l}\text { voida } \\
\text { can, be } \\
\text { allowed to, } \\
\text { feel }\end{array}$ & 17 & $\begin{array}{l}\text { voida } \\
\text { can, be } \\
\text { allowed to, } \\
\text { feel }\end{array}$ & 21 & $\begin{array}{l}\text { lähteä } \\
\text { leave }\end{array}$ \\
\hline 9. & 20 & $\begin{array}{l}\text { alkaa } \\
\text { begin }\end{array}$ & 14 & $\begin{array}{l}\text { lähteä } \\
\text { leave }\end{array}$ & 15 & $\begin{array}{l}\text { tulla } \\
\text { come }\end{array}$ & 16 & $\begin{array}{l}\text { viedä } \\
\text { bring }\end{array}$ \\
\hline 10. & 16 & $\begin{array}{l}\text { viedä } \\
\text { bring }\end{array}$ & 12 & $\begin{array}{l}\text { puhua } \\
\text { talk }\end{array}$ & 14 & $\begin{array}{l}\text { saada } \\
\text { receive, } \\
\text { be allowed } \\
\text { to }\end{array}$ & 15 & $\begin{array}{l}\text { katsoa } \\
\text { watch }\end{array}$ \\
\hline 11. & 14 & $\begin{array}{l}\text { kertoa } \\
\text { tell }\end{array}$ & 11 & $\begin{array}{l}\text { antaa } \\
\text { give }\end{array}$ & 13 & $\begin{array}{l}\text { ottaa } \\
\text { take }\end{array}$ & 15 & $\begin{array}{l}\text { saada } \\
\text { receive, } \\
\text { be } \\
\text { allowed } \\
\text { to }\end{array}$ \\
\hline 12. & 14 & $\begin{array}{l}\text { puhua } \\
\text { talk }\end{array}$ & 11 & $\begin{array}{l}\text { odottaa } \\
\text { wait }\end{array}$ & 13 & $\begin{array}{l}\text { tietää } \\
\text { know }\end{array}$ & 14 & $\begin{array}{l}\text { ajaa } \\
\text { drive }\end{array}$ \\
\hline 13. & 12 & $\begin{array}{l}\text { antaa } \\
\text { give }\end{array}$ & 10 & $\begin{array}{l}\text { alkaa } \\
\text { begin }\end{array}$ & 10 & $\begin{array}{l}\text { ajaa } \\
\text { drive }\end{array}$ & 13 & $\begin{array}{l}\text { antaa } \\
\text { give }\end{array}$ \\
\hline 14. & 10 & $\begin{array}{l}\text { käydä } \\
\text { visit }\end{array}$ & 10 & $\begin{array}{l}\text { ottaa } \\
\text { take }\end{array}$ & 10 & $\begin{array}{l}\text { kertoa } \\
\text { tell }\end{array}$ & 13 & $\begin{array}{l}\text { pitää } \\
\text { keep, } \\
\text { like, } \\
\text { have }\end{array}$ \\
\hline 15. & 9 & \begin{tabular}{|l|} 
saada \\
receive, be \\
allowed to
\end{tabular} & 7 & $\begin{array}{l}\text { tuoda } \\
\text { bring }\end{array}$ & 9 & $\begin{array}{l}\text { kysyä } \\
\text { ask }\end{array}$ & 13 & $\begin{array}{l}\text { päästä } \\
\text { get }\end{array}$ \\
\hline & 9 & \begin{tabular}{|l|} 
voida \\
can, be \\
allowed to, \\
feel
\end{tabular} & & & & & & \\
\hline$\Sigma$ & 325 & & 227 & & 284 & & 343 & \\
\hline (\%) & $36.6 \%$ & & $36.9 \%$ & & $36.7 \%$ & & $33.5 \%$ & \\
\hline
\end{tabular}

Table 3: The 15 most frequent passive predicates in the four sub-corpora and their share of all passive predicates in each sub-corpus (bottom row). Gray shading marks the common predicates that belong to the group of the most frequent passive predicates in all four sub-corpora.

Table 3 shows that in addition to the common predicates, each sub-corpus entails passive predicates that do not belong to the group of the 15 most 
frequent passive predicates in the other sub-corpora. These are: kutsua 'invite, call' (Est-Fin), käydä 'visit' (Est-Fin), odottaa 'wait' (Ger-Fin), tuoda 'bring' (GerFin), tietää 'know' (Orig-Fin-Det), kysyä 'ask' (Orig-Fin-Det), katsoa 'watch' (Orig-Fin-Lit) and päästä 'get' (Orig-Fin-Lit). Except for katsoa 'watch', which does not occur in passive in Ger-Fin at all, all other passive predicates are frequently used in the passive in the other three sub-corpora, although their frequencies do not suffice for the group of 15 most frequent passive predicates. In other words, these passive predicates do not either distinguish translated texts from the non-translated texts or indicate differences between translations from a particular language.

The semantic profile of the most frequent passive predicates is similar between the sub-corpora. According to Table 3, in particular movement verbs (lähteä 'leave', mennä 'go', käydä 'visit' and tulla 'come'), semantically more or less empty verbs whose meaning is specified in the context (olla 'be', panna 'put', tehdä 'do', viedä 'bring', tuoda 'bring', ottaa 'take' and antaa 'give') and communication verbs (kertoa 'tell', puhua 'talk' and sanoa 'say') are used in the passive in all sub-corpora. The group of the most frequent passive predicates also includes the polysemous verbs voida 'can, be allowed to, feel', saada 'receive, be allowed to' and pitää 'keep, like, have'. In Table 3, the different uses of these polysemous verbs have not been separated from each other.

The profile of the sub-corpora is also rather similar when one considers the share of the 15 most frequent passive predicates of all passive predicates (see the bottom row in Table 3 above). The share varies between $33.5 \%$ and $36.9 \%$, and the sub-corpora do not hence differ dramatically from each other. In OrigFin-Lit, the share of the most frequent passive predicates of all passive predicates is lowest, $33.5 \%$, but the difference in comparison to the other subcorpora is still statistically insignificant ${ }^{12}$.

Tables 4-7 below display the collocates of the seven most frequent common passive predicates mennä 'go', lähteä 'leave', olla 'be', sanoa 'say', ottaa 'take', voida 'can' and tehdä 'do' and their variation in the sub-corpora. ${ }^{13}$ The tables entail the collocates of these search words and their position with regard to the search word.

\footnotetext{
${ }^{12} \operatorname{In} \chi^{2}$ test, the $\mathrm{p}$ values were the following: Orig-Fin-Lit vs. Est-Fin $\mathrm{p}=.34$, Orig-Fin-Lit vs. Ger-Fin $\mathrm{p}=.32$, Orig-Fin-Lit vs. Orig-Fin-Det $\mathrm{p}=.35$.

${ }^{13}$ In this study, collocations were defined as co-occurrences appearing at least five times in the immediate context (left five - right five) of the search word.
} 


\begin{tabular}{|c|c|c|c|c|c|c|c|c|c|c|}
\hline \multicolumn{11}{|c|}{ Est-Fin } \\
\hline L5 & L4 & L3 & L2 & L1 & Centre & R1 & $\mathbf{R 2}$ & R3 & R4 & R5 \\
\hline \multirow[t]{12}{*}{$\begin{array}{l}\mathrm{Ja} \\
\text { And }\end{array}$} & $\begin{array}{l}\text { Ja } \\
\text { And }\end{array}$ & $\begin{array}{l}\text { ja } \\
\text { and }\end{array}$ & $\begin{array}{l}\text { että } \\
\text { that }\end{array}$ & $\begin{array}{l}\text { me } \\
\text { we }\end{array}$ & $\begin{array}{l}\text { Sanotaan } \\
\text { say.PASS }\end{array}$ & $\begin{array}{l}\text { vaikka } \\
\text { although }\end{array}$ & $\begin{array}{l}\text { äiti } \\
\text { mother }\end{array}$ & $\begin{array}{l}\text { ja } \\
\text { and }\end{array}$ & $\begin{array}{l}\text { ja } \\
\text { and }\end{array}$ & $\begin{array}{l}\text { ja } \\
\text { and }\end{array}$ \\
\hline & & & $\begin{array}{l}\text { ja } \\
\text { and }\end{array}$ & $\begin{array}{l}\text { nyt } \\
\text { now }\end{array}$ & $\begin{array}{l}\text { Mennään } \\
\text { go.PASS }\end{array}$ & $\begin{array}{l}\text { jo } \\
\text { already }\end{array}$ & & & $\begin{array}{l}\text { oli } \\
\text { was }\end{array}$ & $\begin{array}{l}\text { oli } \\
\text { was }\end{array}$ \\
\hline & & & $\begin{array}{l}\text { me } \\
\text { we }\end{array}$ & $\begin{array}{l}\text { tai } \\
\text { or }\end{array}$ & $\begin{array}{l}\text { Lähdetään } \\
\text { leave.PASS }\end{array}$ & $\begin{array}{l}\text { nyt } \\
\text { now }\end{array}$ & & & & \\
\hline & & & & $\begin{array}{l}\text { kuten } \\
\text { as }\end{array}$ & $\begin{array}{l}\text { Ollaan } \\
\text { be.PASS }\end{array}$ & $\begin{array}{l}\text { niin } \\
\text { so }\end{array}$ & & & & \\
\hline & & & & & $\begin{array}{l}\text { Tehtiin } \\
\text { do.PAST.PASS }\end{array}$ & $\begin{array}{l}\text { pois } \\
\text { away, off }\end{array}$ & & & & \\
\hline & & & & & $\begin{array}{l}\text { Otettiin } \\
\text { take.PAST.PASS }\end{array}$ & & & & & \\
\hline & & & & & $\begin{array}{l}\text { Oltiin } \\
\text { be.PAST.PASS }\end{array}$ & & & & & \\
\hline & & & & & $\begin{array}{l}\text { Tehdään } \\
\text { do.PASS }\end{array}$ & & & & & \\
\hline & & & & & $\begin{array}{l}\text { Sanottiin } \\
\text { say.PAST.PASS }\end{array}$ & & & & & \\
\hline & & & & & $\begin{array}{l}\text { Otetaan } \\
\text { take.PASS }\end{array}$ & & & & & \\
\hline & & & & & $\begin{array}{l}\text { sanotaanko } \\
\text { say.PASS.QUE }\end{array}$ & & & & & \\
\hline & & & & & $\begin{array}{l}\text { voidaan } \\
\text { can.PASS }\end{array}$ & & & & & \\
\hline
\end{tabular}

Table 4: Collocates of the passive predicates mennä 'go', lähteä 'leave', olla 'be', sanoa 'say', ottaa 'take', voida 'can' and tehdä 'do' in the sub-corpus Est-Fin ( 21 slots filled by 12 different lexical items).

\begin{tabular}{|c|c|c|c|c|c|c|c|c|c|c|}
\hline \multicolumn{11}{|c|}{ Ger-Fin } \\
\hline L5 & L4 & L3 & L2 & L1 & Centre & R1 & $\mathrm{R} 2$ & R3 & R4 & R5 \\
\hline \multirow[t]{11}{*}{$\begin{array}{l}\text { Oli } \\
\text { Was }\end{array}$} & $\begin{array}{l}\text { Ei } \\
\text { not }\end{array}$ & & $\begin{array}{l}\text { ja } \\
\text { and }\end{array}$ & $\begin{array}{l}\text { me } \\
\text { we }\end{array}$ & $\begin{array}{l}\text { sanotaan } \\
\text { say.PASS }\end{array}$ & & & $\begin{array}{l}\text { ja } \\
\text { and }\end{array}$ & & \\
\hline & & & & $\begin{array}{l}\text { sitä } \\
\text { it }\end{array}$ & $\begin{array}{l}\text { ollaan } \\
\text { be.PASS }\end{array}$ & & & & & \\
\hline & & & & & $\begin{array}{l}\text { oltiin } \\
\text { be.PAST.PASS }\end{array}$ & & & & & \\
\hline & & & & & $\begin{array}{l}\text { mennään } \\
\text { go.PASS }\end{array}$ & & & & & \\
\hline & & & & & $\begin{array}{l}\text { tehdään } \\
\text { do.PASS }\end{array}$ & & & & & \\
\hline & & & & & $\begin{array}{l}\text { lähdetään } \\
\text { leave.PASS }\end{array}$ & & & & & \\
\hline & & & & & $\begin{array}{l}\text { otetaan } \\
\text { take.PASS }\end{array}$ & & & & & \\
\hline & & & & & $\begin{array}{l}\text { voidaan } \\
\text { can.PASS }\end{array}$ & & & & & \\
\hline & & & & & $\begin{array}{l}\text { tehtäisiin } \\
\text { do. PASS.SUBJ }\end{array}$ & & & & & \\
\hline & & & & & $\begin{array}{l}\text { sanottiin } \\
\text { say. PASS.PAST }\end{array}$ & & & & & \\
\hline & & & & & $\begin{array}{l}\text { voitaisiin } \\
\text { can.PASS.SUBJ }\end{array}$ & & & & & \\
\hline
\end{tabular}

Table 5: Collocates of the passive predicates mennä 'go', lähteä 'leave', olla 'be', sanoa 'say', ottaa 'take', voida 'can' and tehdä 'do' in the sub-corpus Ger-Fin ( 6 slots filled by 5 different lexical items). 


\begin{tabular}{|c|c|c|c|c|c|c|c|c|c|c|}
\hline \multicolumn{11}{|c|}{ Orig-Fin-Det } \\
\hline L5 & L4 & L3 & L2 & L1 & Centre & R1 & $\mathbf{R 2}$ & R3 & R4 & R5 \\
\hline \multirow[t]{10}{*}{$\begin{array}{l}\mathrm{Ja} \\
\text { And }\end{array}$} & $\begin{array}{l}\mathrm{Ja} \\
\text { and }\end{array}$ & & $\begin{array}{l}\text { ja } \\
\text { and }\end{array}$ & $\begin{array}{l}\mathrm{Me} \\
W e\end{array}$ & $\begin{array}{l}\text { mennään } \\
\text { go.PASS }\end{array}$ & $\begin{array}{l}\text { me } \\
\text { we }\end{array}$ & & $\begin{array}{l}\text { ja } \\
\text { and }\end{array}$ & & $\begin{array}{l}\text { ja } \\
\text { and }\end{array}$ \\
\hline & & & & $\begin{array}{l}\text { Nyt } \\
\text { Now }\end{array}$ & $\begin{array}{l}\text { lähdetään } \\
\text { leave.PASS }\end{array}$ & $\begin{array}{l}\text { sitten } \\
\text { then }\end{array}$ & & $\begin{array}{l}\text { oli } \\
\text { was }\end{array}$ & & \\
\hline & & & & $\begin{array}{l}\mathrm{Ja} \\
\text { And }\end{array}$ & $\begin{array}{l}\text { tehdään } \\
\text { do.PASS }\end{array}$ & & & $\begin{array}{l}\text { hän } \\
\text { s/he }\end{array}$ & & \\
\hline & & & & & $\begin{array}{l}\text { Oltiin } \\
\text { be.PASS.PAST }\end{array}$ & & & & & \\
\hline & & & & & $\begin{array}{l}\text { ollaan } \\
\text { be.PASS }\end{array}$ & & & & & \\
\hline & & & & & $\begin{array}{l}\text { sanotaan } \\
\text { say.PASS }\end{array}$ & & & & & \\
\hline & & & & & $\begin{array}{l}\text { voitaisiin } \\
\text { can.PASS.SUBJ }\end{array}$ & & & & & \\
\hline & & & & & $\begin{array}{l}\text { voidaan } \\
\text { can.PASS }\end{array}$ & & & & & \\
\hline & & & & & $\begin{array}{l}\text { otetaan } \\
\text { take.PASS }\end{array}$ & & & & & \\
\hline & & & & & $\begin{array}{l}\text { mentiin } \\
\text { go.PASS.PAST }\end{array}$ & & & & & \\
\hline & & & & & $\begin{array}{l}\text { mennäänkö } \\
\text { go.PASS.QUE }\end{array}$ & & & & & \\
\hline
\end{tabular}

Table 6: Collocates of the passive predicates mennä 'go', lähteä 'leave', olla 'be', sanoa 'say', ottaa 'take', voida 'can' and tehdä 'do' in the sub-corpus Orig-Fin-Det (12 slots filled by six different lexical items).

\begin{tabular}{|c|c|c|c|c|c|c|c|c|c|c|}
\hline \multicolumn{11}{|c|}{ Orig-Fin-Lit } \\
\hline L5 & L4 & L3 & L2 & L1 & Centre & R1 & $\mathbf{R} 2$ & R3 & R4 & R5 \\
\hline $\begin{array}{l}\mathrm{Ja} \\
\text { And }\end{array}$ & $\begin{array}{l}\mathrm{Ja} \\
\text { and }\end{array}$ & $\begin{array}{l}\text { ja } \\
\text { and }\end{array}$ & $\begin{array}{l}\text { ja } \\
\text { and }\end{array}$ & $\begin{array}{l}\text { me } \\
\text { we }\end{array}$ & $\begin{array}{l}\text { mennään } \\
\text { go.PAST }\end{array}$ & $\begin{array}{l}\text { me } \\
\text { we }\end{array}$ & $\begin{array}{l}\text { ja } \\
\text { and }\end{array}$ & $\begin{array}{l}\mathrm{ja} \\
\text { and }\end{array}$ & $\begin{array}{l}\mathrm{ja} \\
\text { and }\end{array}$ & $\begin{array}{l}\mathrm{ja} \\
\text { and }\end{array}$ \\
\hline $\begin{array}{l}\text { On } \\
\text { Is }\end{array}$ & $\begin{array}{l}\text { Oli } \\
\text { was }\end{array}$ & $\begin{array}{l}\text { on } \\
\text { is }\end{array}$ & $\begin{array}{l}\text { että } \\
\text { that }\end{array}$ & $\begin{array}{l}\text { ja } \\
\text { and }\end{array}$ & $\begin{array}{l}\text { oltiin } \\
\text { be.PASS.PAST }\end{array}$ & $\begin{array}{l}\text { jo } \\
\text { already }\end{array}$ & $\begin{array}{l}\text { niin } \\
\text { so }\end{array}$ & $\begin{array}{l}\text { että } \\
\text { that }\end{array}$ & $\begin{array}{l}\text { on } \\
\text { is }\end{array}$ & $\begin{array}{l}\text { on } \\
\text { is }\end{array}$ \\
\hline \multirow[t]{11}{*}{$\begin{array}{l}\text { Se } \\
\text { It }\end{array}$} & & & & $\begin{array}{l}\text { että } \\
\text { that }\end{array}$ & $\begin{array}{l}\text { ollaan } \\
\text { be.PASS }\end{array}$ & $\begin{array}{l}\text { että } \\
\text { that }\end{array}$ & & $\begin{array}{l}\text { sanoi } \\
\text { said }\end{array}$ & & \\
\hline & & & & $\begin{array}{l}\text { sitä } \\
\text { it }\end{array}$ & $\begin{array}{l}\text { tehdään } \\
\text { do.PASS }\end{array}$ & & & $\begin{array}{l}\text { kanssa } \\
\text { with }\end{array}$ & & \\
\hline & & & & $\begin{array}{l}\text { nyt } \\
\text { now }\end{array}$ & $\begin{array}{l}\text { mentiin } \\
\text { go.PASS.PAST }\end{array}$ & & & & & \\
\hline & & & & $\begin{array}{l}\text { kun } \\
\text { when }\end{array}$ & $\begin{array}{l}\text { voidaan } \\
\text { can.PASS }\end{array}$ & & & & & \\
\hline & & & & & $\begin{array}{l}\text { sanotaan } \\
\text { say.PASS }\end{array}$ & & & & & \\
\hline & & & & & $\begin{array}{l}\text { otettiin } \\
\text { take.PASS }\end{array}$ & & & & & \\
\hline & & & & & $\begin{array}{l}\text { lähdetään } \\
\text { leave.PASS }\end{array}$ & & & & & \\
\hline & & & & & $\begin{array}{l}\text { sanottiin } \\
\text { say.PASS.PAST }\end{array}$ & & & & & \\
\hline & & & & & $\begin{array}{l}\text { tehtiin } \\
\text { do.PASS.PAST }\end{array}$ & & & & & \\
\hline & & & & & $\begin{array}{l}\text { lähdettiin } \\
\text { leave.PASS.PAST }\end{array}$ & & & & & \\
\hline & & & & & $\begin{array}{l}\text { otetaan } \\
\text { take.PASS }\end{array}$ & & & & & \\
\hline
\end{tabular}

Table 7: Collocates of the passive predicates mennä 'go', lähteä 'leave', olla 'be', sanoa 'say', ottaa 'take', voida 'can' and tehdä 'do' in the sub-corpus Orig-Fin-Lit (28 slots filled by 11 different lexical items). 
According to these tables, the sub-corpus Ger-Fin displays the smallest number of collocates for these passive predicates (see Table 5). In other words, the neighbouring contexts of these passive predicates show less repetition and more variation than in the other sub-corpora. In Ger-Fin, there are in total five different collocates, which occupy six different positions surrounding the search words. The largest number of collocates appears in Orig-Fin-Lit (see Table 7). In this sub-corpus, the immediate surroundings of these passive predicates exhibit hence more repetition and less variation than in the other sub-corpora. The 11 different collocates occupy 28 different slots before and after the search words in this sub-corpus. The sub-corpora Est-Fin ( 21 slots filled by 12 different lexical items) and Orig-Fin-Det (12 slots filled by six different lexical items) take a middle position between Ger-Fin and Orig-Fin-Lit (see Tables 4 and 6). It would be tempting to interpret this quantitative collocation data for Ger-Fin as a feature supporting previous corpus-linguistic studies, according to which lexical combinations vary more in translated texts than in non-translated comparable texts (see e.g. Mauranen 2000). This conclusion is, however, questioned if one considers the frequency of the seven common passive predicates discussed here (see Table 3). It seems that the number of the collocates is dependent on the frequency of the passive predicates and not on the source language: In GerFin, in which the number of the collocates is lowest, the frequency of the seven shared predicates is also lowest (125 cases). In all the other corpora, the number of the collocates follows the frequency of the seven passive predicates (173 Est-Fin, 178 Orig-Fin-Det and 223 Orig-Fin-Lit). In other words, the higher the frequency of the passive predicates, the higher the number of the collocates. Hence, the collocation data in Tables 4-7 do not reveal properties typical of translations or of translations from a particular language.

Furthermore, the collocates seem to be rather similar in the four sub-corpora. In all sub-corpora, conjunctions (ja 'and', että 'that', kun 'when', tai 'or', vaikka 'although', kuten 'as') appear in the collocation with Tables 4-7 indicating that the passive predicates often occur close to a clausal border. In addition, temporal adverbs (nyt 'now', jo 'already', sitten 'then') are frequent collocates except for Ger-Fin. The subject pronoun me 'we', whose most popular position according to the collocation tables is $\mathrm{L} 1$, is a common collocate in all subcorpora.

In the final phase of the corpus-linguistic analysis the frequency of the subject pronoun me 'we' was studied separately from the other collocates, because its occurrence is an unambiguous indicator for the speaker-inclusive use of the passive. The following Table 8 shows its frequency in the sub-corpora. In this table, which entails both the absolute and relative frequencies of the cooccurrences with me 'we', all passive predicates in each sub-corpus have been taken into consideration. The relative frequency was counted by relating the number of co-occurrences with me 'we' to the total number of passive predicates in each sub-corpus (see Table 2 above). Table 8 shows that the frequency of me 'we' is highest in Orig-Fin-Lit and second highest in Orig-FinDet. In both translated sub-corpora its frequency is lower. 


\begin{tabular}{|l|r|r|}
\hline & Absolute frequency of $m e$ 'we' & Relative frequency (\%) \\
\hline Est-Fin & 35 & 3.9 \\
\hline Ger-Fin & 31 & 5.0 \\
\hline Orig-Fin-Det & 52 & 6.7 \\
\hline Orig-Fin-Lit & 84 & 8.2 \\
\hline
\end{tabular}

Table 8: The subject pronoun me 'we' as a collocate for the passive predicates in the sub-corpora.

On the one hand, the relative frequencies in Table 8 seem to suggest that it is possible that Estonian as a source language influences the speaker-/narratorinclusive use of the Finnish passive. On the other hand, Table 8 indicates a rather clear tendency distinguishing translated and non-translated data. In both translated sub-corpora, the speaker-/narrator-inclusive use with the subject pronoun me 'we' is less frequent than in the non-translated sub-corpora, and the differences are mostly statistically significant ${ }^{14}$. This result is compatible with earlier research according to which literary translators in general tend be more conservative and utilise the means of spoken language less often and in a different way than original writers in the same language (see e.g. Nevalainen 2003).

In sum, the quantitative data and the features studied in this subsection bring out only some evidence for source-text influence on the use of the speakerinclusive passive in literary translations and about the differences between translations and non-translated texts. The strongest piece of evidence for source-text-influenced reduction of the use of the speaker-inclusive passive was the co-occurrence with the subject pronoun me 'we', which was less frequent in translations from Estonian. However, because translations from German also showed a lower frequency for it in comparison to original Finnish literature, it is also possible to conclude that instead of source-text influence this is a feature typical for translated texts in general: Translators regardless of source language simply use features of spoken language less frequently than writers of original Finnish texts. In addition, the share of different passive predicate types of all passive predicates turned out to be lower in both sub-corpora consisting of translations than in original Finnish literature. This means that the lexical variation of the passive, which is lower in translations, could be a feature which distinguishes translations from original Finnish literature. The two translational sub-corpora did not, however, clearly differ from each other with respect to this feature.

All other examined features - the frequency of the passive predicates, the most frequent passive predicates and their profile, the most frequent common passive predicates in the sub-corpora, the share of the common most frequent passive predicates of all passive predicates and the collocates of the common most frequent passive predicates - did not, in contrast, separate translations from

${ }^{14} \ln \chi^{2}$ test, the $p$ values were the following: Est-Fin vs. Ger-Fin $p=.40$, Est-Fin vs. Orig-Fin-Det $p<.05$, Est-Fin vs. Orig-Fin-Lit $p<.001$, Ger-Fin vs. Orig-Fin-Det $p=.26$, Ger-Fin vs. Orig-Fin-Lit $p<.05$, Orig-Fin-Det vs. Orig-Fin-Lit $p=.32$. 
non-translated texts or translations from a particular language from other translations. All in all, the above tested methodology did not manage to detect unambiguously source-language-dependent features in the use of the Finnish passive, and it only weakly identified properties typical of Finnish translations as compared to original Finnish literary texts.

\subsection{Manual semantic analysis}

This final subsection reports the results of a close-reading analysis in which a restricted number of passive predicates was examined in each sub-corpus with regard to speaker-/narrator-inclusive, speaker-/narrator-exclusive and referentially open use (see Section 3). For the manual analysis, we chose passive predicates which appear in all sub-corpora. There were in total 56 such predicates. Of each passive predicate only one occurrence in each corpus was randomly chosen and taken into consideration.

Choosing the speaker/narrator inclusiveness or exclusiveness as the subject of this manual analysis is motivated by the earlier research concerning the Finnish and Estonian passives in contact. Riionheimo (2013) and Riionheimo et al. (2014) report the results of a case study on Ingrian Finnish, a Finnish dialect spoken originally in the territory of Ingria in Russia (around Saint Petersburg). Due to the complex and difficult consequences of the Second World War, many speakers of this Finnish variety migrated to the area of contemporary Estonia, which at the time of their immigration had been conquered by the Soviet Union. In this Soviet-Estonian society, the Ingrian Finns formed a stigmatized group and were considered politically suspicious because of their Finnish origin (even though they had actually been born in Russia). As a consequence, the Ingrian Finns tried to hide their background and avoid using their heritage language ${ }^{15}$ in public places. Simultaneously, they had to acquire a new language, Estonian. In these particular circumstances, the Ingrian Finnish spoken by these migrants developed into a unique blend of features of Ingrian Finnish, the Finnish standard variety, Estonian and (to some extent) Russian (Riionheimo 2007; 2013; Frick \& Riionheimo 2013; Kokko 2007).

The data of Riionheimo et al. (2014) comes from a set of interviews made in the beginning of the 1990's when the speakers had lived in Estonia approximately 50 years. The influence of Estonian is strong in all areas of their language, and it has also affected the use of the Ingrian Finnish passive, whose original functions are similar to the Finnish passive described above. The quantitative analysis, which was based on interviews of 17 informants born in 1911-1930 (in total 81,974 tokens), shows a clear reduction of the use of the speaker-inclusive passive. In the analysis, which was carried out manually, passive predicates in the past tense were collected and grouped into three classes: referentially open, speaker-exclusive and speaker-inclusive passive clauses. The Ingrian Finnish

${ }^{15}$ By heritage language we refer here to the home language of migrant families or other minority communities. Often the term is used in connection with the language variety spoken by the second generation (see e.g. Polinsky 2013), but our usage is somewhat larger in scope and applies to the first-generation immigrants as well. 
data from Estonia was compared to data from comparable interviews of Ingrian Finnish speakers living in Russia, a variety which Estonian has not influenced (8 informants, born in 1911-1927, 61,342 tokens). The comparison showed that the speaker-inclusive use is more common in the Russian data: In the interviews of Ingrian Finnish speakers living in Russia, the frequency of the speaker-inclusive passive was 2.1 / 1,000 words; the frequency of the speakerinclusive passive predicates occurring with the subject pronoun me 'we' (see Ex. 6 above), in turn, was $2.7 / 1,000$ words. In the Estonian data both frequencies were lower: 1.3 / 1,000 words and 1.3 / 1,000 words, respectively. The differences are statistically significant. ${ }^{16}$

The reduction of the speaker-inclusive use of the passive can be regarded as an indirect outcome of a long-term language contact: Since the speaker-inclusive passive is not typical of the language of the majority, Estonian, which had become dominant in the daily life of the informants, its use has decreased in the heritage language of the speakers. This kind of contact effect has been labelled differently in contact linguistics: Dorian (2006) calls it negative borrowing, King (2000) covert interference and Silva-Corvalàn (1994) indirect transfer. All terms refer to the contact-induced reduction or complete loss of elements, constructions or structures which are not shared by the two languages in contact.

The language contact between Estonian and Ingrian Finnish differs in many ways from translation as a type of language contact. In the Estonian context, speakers of different languages have lived for a long time in side-by-side contact with each other, and the language of the majority has been present in the lives of the minority-language speakers in many ways. Many informants had gone through language shift and had started to use Estonian as their home language. Furthermore, the influence of the Estonian majority language concerns primarily a spoken, non-standardized variety. Literary translation, on the contrary, represents a written standard variety or the ways in which translators aim to represent spoken non-standard varieties in writing. Regardless of these differences, the contact-induced reduction of linguistic features not shared by the two languages in contact has been shown to occur in different contact situations, in translation, in attriting heritage languages and in second-language learners' L2 and L1 (Kolehmainen, Meriläinen \& Riionheimo 2014, see also Section 2 above). In translation studies, it has been referred to as the Unique Items Hypothesis (Tirkkonen-Condit 2004). In the following, we examine the question of whether this kind of reduction takes place in literary translation from Estonian to Finnish and affects the speaker-inclusive use of the Finnish passive.

In the manual analysis, the same criteria were used as in the previous study by Riionheimo et al. (2014). There are examples in which the speaker and the narrator overlap and represent the same person, but this is not the case in all examples. The final classification is naturally an interpretation of the researcher,

${ }^{16}$ For inclusive passives $L L=15.91, p<0,0001$; for passives with the pronoun $m e$ 'we' $L L=$ 33.46, $p<0,0001$. 
and not all cases are equally clear. The following examples, which are all taken from the sub-corpus Est-Fin, illustrate the classification.

Passive sentences, which are speaker-/narrator-inclusive, tend to refer to temporally or spatially specific events in which the speaker or the narrator belongs to the group of possible agents. Cases with the subject pronoun me 'we', which authors and translators make use of in order to create the illusion of spoken colloquial style, obviously belong to this group: Example (11) entails a sequence of reported speech in which all predicates are in passive voice and occur with the subject pronoun me 'we':

$\begin{array}{llll}\text { »Me ei } & \text { tiedetä } & \text { mitään } & \text { eikä tunneta } \\ \text { we NEG.3SG know.PASS } & \text { anything } & \text { and-not know.PASS } \\ \text { täällä ketään. Me ollaan } & \text { evakkoja. } & \text { Narvasta [...]. Me } \\ \text { here anyone we be.PASS } & \text { evacuees } & \text { Narva.ELA we } \\ \text { asutaan tässä talossa } & \text { toista } & \text { kuukautta. [...]» } \\ \text { live.PASS this.INE house.INE } & \text { second.PART } & \text { month.PART }\end{array}$

"We don't know [passive in Finnish] anything and we don't know [passive in Finnish] anybody here. We are [passive in Finnish] evacuees. From Narva. We have lived [passive in Finnish] in this house almost two months." (Est-Fin)

Pajusalu (2015) states that there may also be other clues in a referential chain which help to identify the speaker-inclusive use of the passive. In a referential chain, the reference is first anchored to the first-person plural by using the subject pronoun me 'we', after which all the following passive predicates are interpreted as speaker-/narrator-inclusive, although they occur without the subject pronoun me 'we'. This is illustrated in Example (12), in which the anchoring is done in the first speaker's turn:

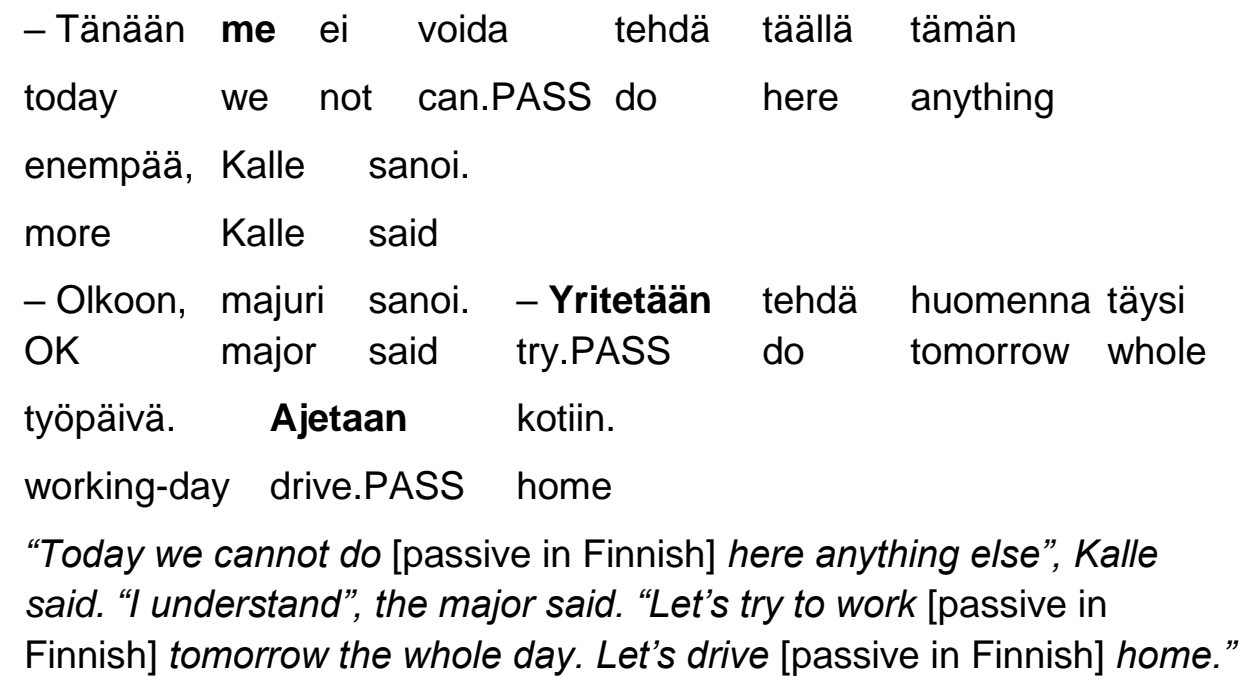

There may also be other clues which reveal that the speaker or the narrator is included. In Example (13) below, the first-person narrator refers first to the persons in the situation by using the first-person plural (kuljimme 'we walked') and then in the first-person singular in the reporting clause (minä kysyin '। 
asked'). In the reported speech, both the narrator and the other person (äiti 'mother') use passive predicates, but the preceding narrative techniques reveal that they are narrator-inclusive.

Kuljimme vielä vähän matkaa ja sitten pysähdyimme. Minä kysyin:

We walked a while and then we stopped. I asked:

"Äiti, miksi nyt pysähdyttiin?" ja äiti selitti:

mom why now stop.PASS.PAST and mom explained

"Nyt odotetaan linjuria."

Now wait.PASS bus.PART

"Mom, why did we stop [passive in Finnish]?" and mother explained:

"Now we wait [passive in Finnish] for the bus."

Speaker-/narrator-exclusive passive sentences, in turn, describe events taking place in a specific temporal frame or location, in which the speaker or the narrator is not involved. Such sentences often refer to events in which the speaker or the narrator is the goal of the activity expressed by the passive predicate:

(14) Vai pitäisikö hänen tehdä suuri harppaus, toisin sanoen painella saman tien Tarttoon ja aloittaa opinnot yliopistossa? Ja toivoa,

Or should he make a major leap, in other words, return to Tartu and start studying at the university? And hope

että hänet otetaan takaisin Urheilulehteen [...]?

that he.ACC take.PASS back Sports Magazine.ILL

that he will be taken back to the Sports Magazine? (Est-Fin)

(15) Kuka nyt enää taloa huoli pitää! Hyvässä lykyssä

Who wants to own a house nowadays! If one is lucky

pidetään $\quad[\ldots]$ kulakkina! (Est-Fin)

consider.PASS kulak.ESS

one is considered as a kulak!

Examples (16) and (17) below illustrate finally the referentially open use of the passive. The passive sentences have been classified as referentially open in cases in which the possible agent in the situation could in principle be anyone and the identity of the agent does not play any role. This is the case in sentences such as (16), which describe generic states of affairs, what people in general do or used to do. In Example (17), in turn, the narrator describes old habits from previous times. 
(16)

- Niin, majuri lisäsi.
"Yes", the major added.
- Puhutaan, että hän olisi yleensäkin ollut
say.PASS that he would in-general have-been
perso naisille [...]
susceptible women.ALL

"It is said that he in general would have been susceptible for women." (Est-Fin)

[...] vedin päälleni avokauluksisen urheilupaidan.

I put on a low-cut singlet.

Sellaisia pidettiin,

They wear.PASS.PAST

\section{They were worn,}

muistat varmaan, kaulus käännettynä takinkäänteiden päälle. (Est-Fin)

you surely remember, so that the collar was turned on the coat collar.

Table 9 summarizes the quantitative results of the manual analysis in which the speaker-/narrator-inclusive, speaker-/narrator-exclusive and referentially open use of the chosen 56 passive predicates was examined in each sub-corpus. It shows that the speaker-/narrator-inclusive use is almost identical in the subcorpora Est-Fin and Ger-Fin, somewhat higher in Orig-Fin-Det and clearly higher in Orig-Fin-Lit. ${ }^{17}$ Our hypothesis, based on the results of Riionheimo et al. (2014) was that, since speaker-inclusiveness does not occur at all or is very rare in original Estonian texts, its occurrences in the Est-Fin translations would be lower than in non-translated Finnish texts. According to Table 9, this is the case in our data, too, since the number of speaker-/narrator-inclusive passives is higher in Orig-Fin-Det and Orig-Fin-Lit than in Est-Fin. However, Ger-Fin has the exact same number of speaker-/narrator-inclusive passive predicates and our data do not hence permit identification of a distinct profile for translations from a particular language. We have to keep in mind, however, that the number of the chosen passive predicates was limited and the results are thus only approximate.

One controversial finding in Table 9 is the number of occurrences of the passive predicates with the subject pronoun me 'we'. Unexpectedly, me 'we' occurs more frequently in translations from Estonian than in the other sub-corpora. This result is contradictory to the results in the previous section, where it was shown that the co-occurrence with me 'we' is lowest in translations from Estonian. In Table 9, the number thus seems to be skewed by too small a sample of selected passive predicates, and this has to be taken into account when assessing the results of this part of our study.

\footnotetext{
${ }^{17}$ Due to the small size of the predicates in this spot check, we chose not to calculate the statistical significance of the differences between the sub-corpora.
} 


\begin{tabular}{|l|r|r|r|r|r|r|r|r|}
\hline & \multicolumn{2}{|c|}{ Est-Fin } & \multicolumn{2}{c|}{ Ger-Fin } & \multicolumn{2}{c|}{$\begin{array}{l}\text { Orig-Fin- } \\
\text { Det }\end{array}$} & \multicolumn{2}{c|}{ Orig-Fin-Lit } \\
\hline & $\mathrm{f}$ & $\%$ & $\mathrm{f}$ & $\%$ & $\mathrm{f}$ & $\%$ & $\mathrm{f}$ & $\%$ \\
\hline a) Referentially open & 12 & 21.4 & 8 & 14.3 & 4 & 7.1 & 2 & 3.6 \\
\hline $\begin{array}{l}\text { b) Speaker-/narrator- } \\
\text { exclusive }\end{array}$ & 24 & 42.9 & 28 & 50.0 & 29 & 51.8 & 20 & 35.7 \\
\hline $\begin{array}{l}\text { c) Speaker-/narrator- } \\
\text { inclusive } \\
\text { (including: me 'we' }+ \\
\text { passive predicate) }\end{array}$ & 20 & 35.7 & 20 & 35.7 & 23 & 41.1 & 34 & 60.7 \\
\hline In total & 56 & $(12.5)$ & $(5)$ & $(8.9)$ & $(4)$ & $(7.1)$ & $(3)$ & $(5.4)$ \\
\hline
\end{tabular}

Table 9: Referentially open, speaker-/narrator-exclusive and speaker-/narrator-inclusive use of the chosen passive predicates. Row $\mathrm{c}$ ) indicates in brackets the occurrences of the examined passive predicates with the subject pronoun me 'we'.

In sum, the manual analysis carried out in this subsection was not conclusive and did not allow detection of clear differences between translations and nontranslated texts or properties typical of translations from a particular source language. The number of speaker-/narrator-inclusive passive predicates was identical in the two translated corpora (Est-Fin and Ger-Fin) and only slightly bigger in one of the non-translated corpora, Orig-Fin-Det. Original Finnish literature (Orig-Fin-Lit), however, showed a different profile and a more frequent use of the speaker-/narrator-inclusive passive.

\section{Conclusion}

The goal of this article was to test the possibilities - and possible limitations - of corpus-linguistic tools when analysing the use of the Finnish passive in literary texts. In addition, the article pursued the question whether translation as a type of language contact affects the use of the Finnish passive in a similar way as an oral language contact situation in which the speakers of two different languages have long lived side-by-side and in which the majority language has affected the use of the Finnish passive. For this purpose, the use of the Finnish passive was investigated in a corpus of Finnish literary translations from Estonian and German and in comparable Finnish non-translated literary texts. The results of the manual analysis of corpus data were then related to the results of a previous study on the contact-induced changes in the use of the Finnish passive among a particular group of Finnish migrants in Estonia.

All in all, the tested corpus-linguistic methodology allowed only weakly indicative properties typical of Finnish translations as compared to original Finnish literary texts or properties typical of Finnish translations from a particular source language. The most convincing piece of evidence for source-text-influenced features in the use of the Finnish passive in literary translations concerned the co-occurrence with the subject pronoun me 'we', which was less frequent in translations from Estonian than in the other sub-corpora. In other words, in translations from Estonian the speaker-inclusive use of the Finnish passive appears to have been reduced in a similar way as in the oral language-contact 
situation with which this result was compared. It was not, however, possible to exclude the possibility that the lower frequency of the speaker-inclusive use is a typical feature of translated texts in general, since translations from German also showed a lower frequency for it in comparison to original Finnish literature. In addition, the lexical variation in the passive proved to be narrower in translations than in original Finnish literature.

The possible reasons for the mainly non-conclusive nature of the analysis may be the data or the manually driven method. The sub-corpora formed for this pilot study may still be too small and reflect text- or genre-specific stylistic preferences. Additionally, the size of the passive predicate samples and the number of the passive predicate occurrences examined manually may have been too small. It may have happened, for example, that in the texts translated from Estonian into Finnish (Est-Fin) the randomly chosen predicates have occurred in dialogue and represent spoken language - this might explain the surprisingly frequent use of the pronoun me 'we' (see Table 9). Furthermore, different books may contain a different amount of dialogue and the texts may thus not be fully comparable. In addition, the methodology may have to be adjusted in future studies and more in-depth methods developed in order to acquire a fuller picture of the passive in literary texts. For example, due to the frequency of the Finnish passive in literary texts, automated methods of analysis, which require morphosyntactic annotation of the corpora, would be helpful. What is also needed is a comprehensive study of the passive as used by Finnish authors, which would enable a comparison and confirmation of what is author, translator, genre or source-language specific in the use of the Finnish passive.

Finally, one should not forget the possibility that the analysis was weakly conclusive because there simply is no source-language-dependent use of the passive and the source language does not steer translators' choices. It is possible that no similar contact-induced reduction of the speaker-inclusive passive use takes place in translation in the first place and that translation as a mode of language contact simply operates differently than a long-term oral contact situation in which speakers of a minority language have been exposed to the majority language and in which they have had to suppress the use of their mother tongue.

\section{Primary sources}

Est-Fin:

Kross, Jaan 1999: Paikallaanlento: Ullo Paerandin romaani. [Orig.: Paikallend.] Translated by Jouko Vanhanen. Porvoo etc.: WSOY. [From the Corpus of Translated Finnish]

Luik, Viivi 1985: Seitsemäs rauhan kevät. Translated by Eva Lille. [Orig.: Seitsmes rahukevad.] Helsinki: Tammi.

Paju, Juhan 1992: Haapsalun saunamurhat. [Orig.: Haapsalu detektiiv.] Translated by Samuli Juvonen. Helsinki: Taifuuni. 


\section{Ger-Fin:}

Lenz, Siegfried 1997: Sointikoe. Translated by Leena Vallisaari. [Orig.: Die Klangprobe.] Jyväskylä: Gummerus. [From the Finnish-German FinDe corpus]

Noll, Ingrid 1997: Kukko on kuollut. Translated by Oili Suominen. [Orig.: Der Hahn ist tot.] Porvoo etc.: WSOY. [From the Corpus of Translated Finnish]

Schulze, Ingo 1999: Simple storys. Translated by Liisa Laaksonen. [Orig.: Simple storys.] Helsinki: Otava. [From the Finnish-German FinDe corpus]

Orig-Fin-Det [All texts from the Corpus of Translated Finnish]:

Jokinen, Seppo 1999: Koskinen ja taikashow. Hämeenlinna: Karisto.

Matintupa, Tuula T.1999: Piippo ja mies Marokosta. Karkkila: Kustannus Mäkelä.

Pakkanen, Outi 1999: Macbeth on kuollut. Helsinki: Otava.

Sinisalo, Mikko 1998: Tiilet tietävät kuolemaa. Helsinki: Yliopistopaino.

Tuomainen, Jukka 1999: Saunavieras. Helsinki: Yliopistopaino.

Orig-Fin-Lit [All texts from the Corpus of Translated Finnish]:

Hassinen, Pirjo 1998: Viimeinen syli. Helsinki: Otava.

Kylätasku, Jussi 2000: Jalmarin toinen tuleminen. Porvoo etc.: WSOY.

Mörö, Mari 1998: Kiltin yön lahjat. Porvoo etc.: WSOY.

Salminen, Arto 1998: Varasto. Porvoo etc.: WSOY.

Tuominen, Taija 2000: Tiikerihai. Porvoo etc.: WSOY.

\section{References}

Amouzadeh, Mohammad \& House, Juliane (2010). Translation as a Language Contact Phenomenon, Languages in Contrast 10(1), 54-75.

Baker, Mona (1993). Corpus Linguistics and Translation Studies. Implications and Applications. Text and Technology. In Honour of John Sinclair, eds. Mona Baker, Gill Francis \& Elena Tognini Bonelli. Amsterdam and Philadelphia: John Benjamins, 233-250.

Baumgarten, Nicole \& House, Juliane \& Probst, Julia (2004). English as Lingua Franca in Covert Translation Processes, The Translator 10(1), 83-108.

Baumgarten, Nicole \& Özçetin, Demet (2008). Linguistic Variation through Language Contact in Translation. Language Contact and Contact Languages, eds. Peter Siemund \& Noemi Kintana. Amsterdam and Philadelphia: John Benjamins, 293316.

Becher, Viktor \& House, Juliane \& Kranich, Svenja (2009). Convergence and Divergence of Communicative Norms through Language Contact in Translation. Convergence and Divergence in Language Contact Situations, eds. Kurt Braunmüller \& Juliane House. Amsterdam and Philadelphia: John Benjamins, 125151. 
Bernardini, Silvia (2010). Parallel Corpora and the Search for Translation Norms/Universals. Keynote Talk at the Symposium "MATS 2010. Methodological Advances in Corpus-based Translation Studies". Gent, Belgium, January 8-9, 2010.

Bernardini, Silvia \& Ferraresi, Adriano (2011). Practice, Description and Theory Come Together: Normalization or Interference in Italian Technical Translation?, Meta. Translators' Journal 56(2), 226-246.

Blevins, James P. (2003). Passives and Impersonals, Journal of Linguistics 39, 473520.

Duden = Duden. Die Grammatik (2009). Ed. by the Duden Editiorial Board. 8., Revised Edition. Mannheim: Dudenverlag.

EKG I = Eesti keele grammatika I (1995). Ed. by Mati Erelt, Reet Kasik, Helle Metslang, Henno Rajandi, Kristiina Ross, Henn Saari, Kaja Tael \& Silvi Vare. Tallinn: Eesti Teaduste Akadeemia Eesti Keele Instituut.

EKG II = Eesti keele grammatika II (1993). Ed. by Mati Erelt, Reet Kasik, Helle Metslang, Henno Rajandi, Kristiina Ross, Henn Saari, Kaja Tael \& Silvi Vare. Tallinn: Eesti Teaduste Akadeemia Eesti Keele Instituut.

Eskola, Sari (2002). Syntetisoivat rakenteet käännössuomessa. Suomennetun kaunokirjallisuuden ominaispiirteiden tarkastelua korpusmenetelmillä. Joensuu: University of Joensuu.

--- (2004). Untypical Frequencies in Translated Language. A Corpus-based Study on a Literary Corpus of Translated and Non-translated Finnish. Translation Universals. Do they exist? Eds. Anna Mauranen \& Pekka Kujamäki. Amsterdam and Philadelphia: John Benjamins, 83-99.

Even-Zohar, Itamar (1990). Polysystem Studies, Poetics Today 11(1).

Frick, Maria \& Riionheimo, Helka (2013). Bilingual Voicing. A Study of Code-switching in the Reported Speech of Finnish Immigrants in Estonia, Multilingua 32(5), 565-599.

Helasvuo, Marja-Liisa (2006). Passive - Personal or Impersonal? A Finnish Perspective. Grammar from the Human Perspective. Case, Space and Person in Finnish, ed. Marja-Liisa Helasvuo. Amsterdam and Philadelphia: John Benjamins, 233-255.

Hyvärinen, Irma (1996). Passivrestriktionen im Deutschen aus der Perspektive des finnischen DaF-Unterrichts, Triangulum. Germanistisches Jahrbuch für Estland, Lettland und Litauen, 111-142.

Jantunen, Jarmo (2004). Suomennosten kieliasu puntarissa, Virittäjä 4, 531-558.

Jokela, Hanna (2012). Nollapersoonalause suomessa ja virossa. Tutkimus kirjoitetun kielen aineistosta. Turku: University of Turku.

Kaiser, Elsi \& Vihman, Virve-Anneli (2006). Invisible arguments. Effects of Demotion in Estonian and Finnish. Demoting the Agent: Passive, Middle, and other Voice Phenomenon, ed. Torgrim Solstad. Amsterdam: Benjamins, 121-141.

Kittilä, Seppo (2000). Passiivin prototyypistä. Näkökulmia kielitypologiaan, ed. Anneli Pajunen. Helsinki: SKS, 286-312.

Kokko, Ossi (2007). Inkerinsuomen pirstaleisuus. Eräiden sijojen kehitys murteen yksilöllistymisen kuvastajana. Joensuu: University of Joensuu. 
Kolehmainen, Leena (2011a). Source Language Influence without the Effect of "Shining Through". Over-representation of Generic Person Reference in Translations.

Beyond Borders - Translations Moving Languages, Literatures and Cultures, ed. Pekka Kujamäki, Leena Kolehmainen, Esa Penttilä \& Hannu Kemppanen. Berlin: Frank \& Timme, 215-245.

--- (2011b). Variierende Tendenzen in der Übersetzung der dritten Person Singular, Trans-kom, Journal of Translation and Technical Communication Research 4(2), 112-136. Available at: http://www.trans-kom.eu/index-en.html.

--- (2013). Die Unikat-Hypothese der Translation. Etwas Altes, etwas Neues und etwas Geliehenes. Thesen, Theorien und Tendenzen der finnischen Translationswissenschaft, eds. Leena Kolehmainen \& Pekka Kujamäki. Special issue of trans-kom, Journal of Translation and Technical Communication Research 6(1), 92-114. Available at: http://www.trans-kom.eu/index-en.html.

--- (2014). The translation of Null Subjects: A Test Case for the Explicitation Hypothesis? Across Languages and Cultures 15(1), 25-51.

Kolehmainen, Leena \& Meriläinen, Lea \& Riionheimo, Helka (2014). Interlingual Reduction. Evidence from Language Contacts, Translation and Second-language Acquisition. Language Contacts at the Crossroads of Disciplines, eds. Heli Paulasto, Lea Meriläinen, Helka Riionheimo \& Maria Kok. Newcastle upon Tyne: Cambridge Scholars Publishing, 3-32.

Kranich, Svenja (2014). Translation as a Locus of Language Contact. Translation. A Multidisciplinary Approach, ed. Juliane House. London: Palgrave Macmillan, 96115.

Kranich, Svenja \& Becher, Viktor \& Höder, Steffen (2011). A Tentative Typology of Translation-induced Language Change. Multilingual Discourse Production. Diachronic and Synchronic Perspectives, eds. Svenja Kranich, Viktor Becher, Steffen Höder \& Juliane House. Amsterdam and Philadelphia: John Benjamins, 1143.

Lanstyák, István \& Heltai, Pál (2012). Universals in Language Contact and Translation, Across Languages and Cultures 13(1), 99-121.

Laviosa, Sara (1996). The English Comparable Corpus (ECC). A Resource and a Methodology for the Empirical study of Translation. Unpublished Doctoral Disseration, University of Manchester.

Makkonen-Craig, Henna (2005). Toimittajan läsnäolo sanomalehtitekstissä. Näkökulmia suomen kielen dialogisiin passiivilauseisiin. Helsinki: SKS.

Mauranen, Anna (2000). Strange Strings in Translated Language. A Study on Corpora. Intercultural Faultlines. Research Models in Translation Studies 1. Textual and Cognitive Aspects, ed. Maeve Olohan. Manchester: St. Jerome, 119-141.

--- (2004). Corpora, Universals and Interference. Translation universals. Do they exist? Eds. Anna Mauranen \& Pekka Kujamäki. Amsterdam and Philadelphia: John Benjamins, 65-82.

Mauranen, Anna \& Tiittula, Liisa (2005). MINÄ käännössuomessa ja supisuomessa. Käännössuomeksi. Tutkimuksia suomennosten kielestä, eds. Anna Mauranen \& Jarmo H. Jantunen. Tampere: Tampere University Press, 35-69. 
McLaughlin, Mairi (2011). Tradurre/Tradire: Translation as a Cause of Linguistic Change from Manuscripts to the Digital Age. UC Berkeley, The University Library New Faculty Lecture Series. Berkeley: The Doe Library.

Neumann, Stella (2011). Assessing the Impact of Translations on English-German Language Contact. Some Methodological Considerations. Multilingual Discourse Production. Diachronic and Synchronic Perspectives, eds. Svenja Kranich, Viktor Becher, Steffen Höder \& Juliane House. Amsterdam: John Benjamins, 233-256.

Nevalainen, Sampo (2003). Käännöskirjallisuuden puhekielisyyksistä - kaksinkertaista illuusiota? Virittäjä 1, 2-26.

Nirvi, R. E. (1947). Passiivimuotojen aktiivistumisesta, Suomi 104, 5-47. Helsinki: SKS.

Ožbot, Martina (2014). The Case for a Common Framework for Transfer-related Phenomena in the Study of Translation and Language Contact. Language Contacts at the Crossroads of Disciplines, eds. Heli Paulasto, Lea Meriläinen, Helka Riionheimo \& Maria Kok. Newcastle upon Tyne: Cambridge Scholars Publishing, 131-160.

Pertilä, Laura (2000). Passiivimuotojen aktiivistuminen suomen kielessä, Sananjalka 42, 115-139.

Polinsky, Maria (2013). Annotated Bibliography of Research in Heritage Languages. Oxford Bibliographies, Linguistics. Oxford: Oxford University Press. Accessed 18 April 2015.

Posio, Pekka \& Vilkuna, Maria (2013). Referential Dimensions of Human Impersonals in Dialectal European Portuguese and Finnish, Linguistics 51(1), 177-229.

Quirk, Randolph \& Greenbaum, Sidney \& Leech, Geoffrey \& Svartvik, Jan (1985). A Comprehensive Grammar of the English Language. London \& New York: Longman.

Riionheimo, Helka (2007). Muutoksen monet juuret. Oman ja vieraan risteytyminen Viron inkerinsuomalaisten imperfektinmuodostuksessa. Helsinki: SKS.

--- (2013). Colliding Passives. A Morphosyntactic Perspective on Finnic Language Contacts, Võro instituudi toimõndusõq 27, 85-101.

Riionheimo, Helka \& Kolehmainen, Leena \& Meriläinen, Lea (2014). Suomen passiivi kontaktissa. Kieltenvälisiä kytköksiä migraatiossa, toisen kielen omaksumisessa ja kääntämisessä, Virittäjä 3, 334-371.

Shore, Susanna (1986). Onko suomessa passiivia. Helsinki: SKS.

--- (1988). On the So-called Finnish Passive, Word 39, 151-176.

Steiner, Erich (2008). Empirical Studies of Translations as a Mode of Language Contact. "Explicitness" of Lexicogrammatical Encoding as a Relevant Dimension. Language Contact and Contact Languages, eds. Peter Siemund \& Noemi Kintana. Amsterdam and Philadelphia: John Benjamins, 317-346.

Thomason, Sarah G. (2001). Language Contact. An Introduction. Washington, D.C.: Georgetown University Press.

Thomason, Sarah Grey \& Kaufman, Terrence (1988). Language Contact, Creolization, and Genetic Linguistics. Berkeley: University of California Press.

Tiittula, Liisa \& Nuolijärvi, Pirkko (2013). Puheen illuusio suomenkielisessä kaunokirjallisuudessa. Helsinki: SKS. 
Tiittula, Liisa \& Schwitalla, Johannes (2009). Mündlichkeit in literarischen Erzählungen: Sprach- und Dialoggestaltung in modernen deutschen und finnischen Romanen und deren Übersetzungen. Tübingen: Stauffenburg.

Tirkkonen-Condit, Sonja (2004). Unique Items - Over- or Under-represented? Translation universals. Do they exist? Eds. Anna Mauranen \& Pekka Kujamäki. Amsterdam and Philadelphia: John Benjamins, 184-177.

Tommola, Hannu (1993). Ambipersoonainen suppressiivi. Diateesista suomessa ja virossa. Studia comparativa linguarum orbis Maris Baltici 1. Tutkimuksia syntaksin ja pragmasyntaksin alalta, ed. Valma Yli-Vakkuri. Turku: University of Turku, 41-96.

Torn-Leesik, Reeli (2015). An Investigation of Voice Constructions in Estonian. Dissertationes Linguisticae Universtias Tartuensis 26. Tartu: University of Tartu Press.

Torn-Leesik, Reeli \& Vihman, Virve-Anneli (2010). The Uses of Impersonals in Spoken Estonian, SKY Journal of Linguistics 23, 301-343.

Toury, Gideon (1995). Descriptive Translation Studies and Beyond. Amsterdam: Benjamins.

Vilkuna, Maria (2000). Suomen lauseopin perusteet. Helsinki: Kotimaisten kielten tutkimuskeskus \& Edita.

VISK = Iso suomen kielioppi (2004). Ed. by Auli Hakulinen, Maria Vilkuna, Riitta Korhonen, Vesa Koivisto, Tarja Riitta Heinonen \& Irja Alho. Helsinki: SKS. Available also at: http://scripta.kotus.fi/visk.

Wurm, Andrea (2008). Translatorische Wirkung. Ein Beitrag zum Verständnis von Übersetzungsgeschichte als Kulturgeschichte am Beispiel deutscher Übersetzungen französischer Kochbücher in der Frühen Neuzeit. Frankfurt/.M.: Peter Lang.

\section{Appendix: Grammatical abbreviations}

The following grammatical abbreviations occur in the tables and examples.

3 (etc.) 3rd person

ABL Ablative case

ACC Accusative case

ALL Allative case

CLIT Clitic pragmatic particle

DEF Definite article

ELA Elative case

ESS Essive case

GEN Genitive case

ILL Illative case

INE Inessive case

NEG Negation verb 
PART Partitive case

PASS Passive suffix

PAST Past tense

PL Plural

PX Possessive suffix

QUE Clitic question-marking particle

SG Singular

SUBJ Subjunctive mood 